\title{
Effects of breed and dietary experience on juniper con- sumption by goats
}

\author{
R.K. PRITZ, K.L. LAUNCHBAUGH, AND C.A. TAYLOR, JR.
}

Authors are assistant county agent, Texas Agricultural Extension Service, Decatur, Tex. 76234; assistant professor, Range Resources Dept., University of Idaho, Moscow, Ida. 83844; and associate professor, Texas Agricultural Experiment Station, P.O. Box 918, Sonora, Tex. 76950. At the time of the research, the senior and second authors were researchers in the Range, Wildlife, and Fisheries Management Department, Texas Tech University, Lubbock, Tex. 79409.

Abstract

Low nutritional quality and high levels of essential oils result in low consumption of juniper by goats. In this study we examined: (1) if juniper consumption could be increased by exposing goats to essential oils early in life; (2) if goat breeds (Spanish vs Angora) differed in juniper consumption; (3) if differences in juniper consumption were related to detoxification abilities of goats; and, (4) if differences in digestibility and nitrogen or energy balance could explain juniper consumption patterns. In the first experiment, Spanish and Angora goats 6-7 weeks old, were bolused every other day for 1 month with essential oils distilled from redberry juniper (Juniperus pinchotii Sudw.), while control animals received empty capsules. Goats were then offered redberry juniper branches in a 5-day acceptance trial. Spanish goats consumed more $(p<0.01)$ juniper during the trial than Angoras. Goats previously dosed with essential oils ingested marginally less $(p<0.086)$ juniper than controls. Liver-specific enzymes in blood serum (aspartate aminotransferase and gamma glutamyltransferase) were compared before and after acceptance testing to examine potential liver damage. Spanish goats apparently experienced less tissue damage in response to juniper consumption than Angora goats. A second experiment examined the digestion and metabolism of juniper. Spanish goats consumed more ( $p<0.01$ ) juniper than Angora goats though Angoras digested juniper more completely; probably a result of their lower consumption. The metabolic fate of dietary nitrogen and energy was similar for both breeds and unaffected by exposure to essential oils early in life.

Key Words: goats, detoxification, juniper, liver activity, breed differences, preference, early experience, diet history

Several juniper species (Juniperus spp.) occupy millions of hectares throughout western North America (West 1991). Invasion of juniper generally lowers forage availalbility for livestock and wildlife by decreasing herbaceous plant production (Schoot and Pieper 1985, Dye et al. 1995). Juniper is generally considered unpalatable and is seldom consumed by livestock except during winter when herbaceous forage is dormant and other browse has lost its leaves (Smith and Hubbard 1954). Goats

This document is a contribution of the College of Agricultural Sciences and Natural Resources at Texas Tech University No. T-9-752.

Manuscript accepted 16 Dec. 1996.

\section{Resúmen}

Baja calidad nutritiva y alto contenido de aceites esenciales resultan en bajo consumo de juniperio por cabras. En este estudio examinamos: (1) si el consumo de junipero podria aumentarse mediante una exposición de las cabras a aceites esenciales temprano en la vida; (2) si razas de cabras (cabras Española contra Angora) difieren en el consumo de junipero; (3) si las diferencias en el consumo de junipero están relacionadas a la habilidad de desintoxicación de las cabras; y, (4) si diferencias en digestibilidad y balance de nitrógeno ó energia explican los diferentes partrones de consumo de junipero. En el primer experimento cabras de raza cabras Española y Angora de 6-7 semanas de edad fueron dosificadas dia por medio durante un mes con cápsulas de aceites esenciales destilados de junipero de bayas rojas (Juniperus pinchotti Sudw.), mientras que animales control recibieron cápsulas vacias, Posteriormente, a las cabras se les ofrecieron remas de juniper durante una prueba de aceptabilidad que duró 5 dia. Las cabras Española consumieron más ( $<$ 0.01) junipero que las Angora durante la prueba. Las cabras que fueron dosificadas con aceites esenciales consumieron casi menos $(p<0.080)$ junipero que los controles. Niveles de enzimas hepáticas especificas en el plasma antes y después del prueba de aceptabilidad (aspartato aminotransferasa y gama glutamiltransferasa) fueron comparadas para determinar si hubo daño hepático. Cabras Española parecieron sufrir menos daño de tejido hepático que cabras Angora. Un segundo experimento examinó la digestión y el metabolismo del junipero. Cabras Española consumieron más ( $p<0.01$ ) junipero que cabras Angora, pero las cabras Angora digirieron el junipero más completamente: probablemente a consecuencia del menor consumo. El destino del nitrógeno y la energia de la dieta fue similar en ambas razas, y no fue afectado por la dosificación de aceites esenciales temprano en la vida.

have been used in the biocontrol of juniper with high grazing pressure (Taylor 1992). Biocontrol could be enhanced and accomplished at lower stocking rates if the reasons for low juniper consumption were well understood.

Junipers contain essential oils which are monoterpene allelochemicals (Gershenzon and Croteau 1991). The low palatability of juniper is usually attributed to essential oils through (1) their inhibitory effects on rumen microorganisms (Schwartz et al. 1980, Nagy and Tengerdy 1968, Oh et al. 1967); (2) their negative effect on liver metabolism (Huston et al. 1994); or (3) nega- 
tive post-ingestive feedback resulting in conditioned taste aversions (Provenza et al. 1992, Higgins et al. 1996).

Animals possess many behavioral and metabolic mechanisms to avoid or overcome the negative effects of plant allelochemicals (Lindroth 1988, Launchbaugh 1996). Several studies have shown that consumption of specific foods early in life can increase consumption of those foods later in life (Bratmann and Carpenter 1982, Distel and Provenza 1991). It is believed that experience early in life plays a pivotal role in an animal's ability to consume, digest, and detoxify specific foods (Provenza and Balph 1988, Lindroth 1988, Squibb et al. 1990, Distel and Provenza 1991). We hypothesized that essential oils administered to young goats would enhance their ability to metabolize and detoxify the terpenes of juniper.

The objective of this study was to determine the effect of earlylife dietary experience with the essential oils of juniper on the acceptance of juniper by Spanish and Angora goats later in life. Juniper digestibility, nitrogen retention, and metabolizable energy were compared in a standard digestion trial to understand and explain differences in juniper consumption. Blood serum concentration of 2 enzymes was also monitored to diagnose hepatic necrosis.

\section{Materials and Methods}

Research was conducted during the summer of 1994 at the Texas Agricultural Experiment Station $53 \mathrm{~km}$ south of Sonora, Tex. Subjects were 24 Spanish goats and 24 Angora goats. Goats were born and raised in pens void of vegetation to ensure that they were naive to juniper at the time of study.

\section{Experiment 1: Juniper Acceptance}

When goats were 6-7 weeks old they were weaned and randomly selected to be cxposed (treated) or not exposed (controls) to essential oils from redberry juniper (Juniperus pinchotii Sudw.). A combination of breed (Spanish or Angora) and exposure (treatment or control) yielded 4 possible treatments with 12 goats in each treatment combination.

The leaves of randomly selected redberry juniper trees were stripped by hand, bagged, mixed throughly, and stored in a freezer $\left(-15^{\circ} \mathrm{C}\right)$. Male redberry juniper was used because it was abundant and less preferred by livestock than other junipers in the area (Straka 1993). Once sufficient quantities of leaves were obtained they were taken from the freezer and submerged in liquid nitrogen to facilitate leaf disarticulation. The leaves were then combined with water in a large steam distillation apparatus and steam distilled for 4 hours (Clevenger 1928). The distillate was collected in a flask and essential oils were isolated from water with a separatory funnel. All distilled essential oils were composited and stored in a freezer $\left(-15^{\circ} \mathrm{C}\right)$. Four samples $(4 \mathrm{ml} / \mathrm{sample})$ of the composited oil mixture were taken for determination of specific terpene composition and stored at $-50^{\circ} \mathrm{C}$ until analyzed. Terpene composition was determined with an HP579A gas chromatograph as outlined by Straka (1993). The essential oils were analyzed for their composition of 11 terpenes (Table 1) known to occur in redberry juniper (Straka 1993).

\footnotetext{
${ }^{T}$ Experimental animal procedures were approved by the Texas Tech University
} Animal Care and Use Committee protocol \# 94386.
Table 1. Percent concentrations of terpenes extracted from redberry juniper used to give early dietary experience to Spanish and Angora goats naive to juniper.

\begin{tabular}{lc}
\hline \hline Terpenes (Essential oils) & $\%$ Concentration \\
\hline$\alpha$-pinene & 2.30 \\
Camphene & .70 \\
Sabinene and $\beta$-pinene & 22.63 \\
Myrcene & 5.87 \\
Cymene & 1.41 \\
Limonene & 6.34 \\
Camphor & .51 \\
Terpineol & .54 \\
Carvone & 1.85 \\
Bornyl acetate & 3.26 \\
Unidentified & 54.59 \\
\hline
\end{tabular}

\section{Conditioning Period}

The experiment was divided into 2 phases: conditioning and acceptance testing. Conditioning lasted for 32 days during which goats had ad libitum access to a $19 \%$ crude protein pelleted ration and water. Goats assigned to the treatment group were given doses of the essential oil mixture every other day during conditioning (16 doses). Essential oils were administered to the treatment animals in gelatin capsules with a balling gun while control goats were given empty capsules at 0900 hours. The doses were given in increasing increments of $0.03,0.07,0.11$, and $0.22 \mathrm{ml} / \mathrm{kg}$ body wt in weeks 1 through 4 , respectively. The maximum dose was based on preliminary research showing that $0.22 \mathrm{ml} / \mathrm{kg}$ body wt induced mild food aversions in yearling Angora goats (unpublished data, Pritz). During the final 5 days of the conditioning period, goats were individually penned and offered netleaf hackberry (Celtis riticulata Torr.) branches for 1 hour each morning. This familiarized goats with the experimental setting and procedures for the acceptance trial and gave them experience eating live vegetation.

\section{Acceptance Testing}

Acceptance testing lasted 5 days. Btanches from male redberry junipers were offered to goats individually. Branches were selected randomly from within the browse line of trees and clipped daily to reduce volatilization of oils after harvest. Branches were weighed and then offered to goats from 0800 to 1200 hours. Grams consumed were calculated as the difference between amount offered and amount remaining (at 1200 hours) with adjustments for moisture loss. Three branches were hung outside of the goat pens and weighed at 0800 and 1200 hours to monitor moisture loss during each test. Amount refused was adjusted for moisture loss as follows: adjusted amount refused $=$ amount refused + (amount refused $* \%$ moisture loss). During testing. goats received no other basal feed to insure maximum juniper consumption without confounding from varying nutrient intake.

\section{Blood Enzyme Collection and Analysis}

Blood samples were collected for determination of aspartate aminotransferase (AST) and gamma glutamyltransferase (GGT) as predictors of liver damage (Comelius 1980, McCurnin 1990, Radostits et al. 1994). Blood was collected via jugular veinpuncture 1 day before the conditioning period, to establish baseline enzyme levels, 1 day before acceptance testing, and immediately following the acceptance test on day 5. Serum was extracted by 
centrifuging blood at $>1000 \times \mathrm{g}$ for 20 minutes. Serum from each goat was divided into 2 aliquots. Serum for determination of AST enzyme concentrations was refrigerated while serum for GGT determination was frozen before analysis by the Clinical Pathology Laboratory at Texas Tech University, Health Science Center, $36014^{\text {th }}$ Street, Lubbock, Tex. 79430.

\section{Statistical Design}

The statistical design for the acceptance test was a $2 \times 2$ factorial analysis of variance with the factors breed (Spanish vs. Angora) and essential oil exposure (treated vs. control). The trial was repeated for 5 consecutive days requiring repeated-measures analysis (Winer 1971). Enzyme data were also analyzed as a $2 \times 2$ factorial with the baseline enzyme levels serving as a co-variate while collections 2 (after conditioning) and 3 (after acceptance testing) represented repeated measures. One goat was dropped from enzyme analysis because of excessively erratic measurements.

\section{Experiment 2: Juniper Digestibility and Metabolism}

A second experiment was conducted to study the apparent digestibility, nitrogen retention, and metabolizable energy of juniper by Spanish and Angora goats. We hypothesized that potential differences in juniper consumption by breed or individuals may be explained by differences in their ability to digest and metabolize juniper.

A digestion trial was conducted immediately following experiment 1. Goats from experiment 1 were ranked, within treatment groups (1-12), based on their juniper consumption. Because of a limited number of metabolism stalls, the 4 goats with the highest and 4 goats with the lowest juniper consumption from each breed by treatment combination were used in this trial resulting in 32 animals tested. Eight metabolism stalls were available for experimentation necessitating 4 trials with each breed (Spanish or Angora), exposure group (treated or control), and consumption levels (high or low) occurring in each trial.

The goal of the digestion trials was to determine if breeds or exposure groups differed in their ability to digest juniper or utilize the nitrogen and energy from juniper. However, it was anticipated (based on Riddle 1993) that animals could not be maintained on diets soley of juniper for extended time periods. An experimental procedure was therefore used to first measure the digestion of juniper offered with a basal ration, then, measure the digestion of the basal ration (Maynard et al. 1979, Van Soest 1982). The experiment consisted of a 5-day juniper with basal ration adjustment period, 5-day juniper with basal ration digestion trial, 5-day basal ration adjustment period, and a 5-day basal ration digestion trial. Goats were weighed before and after each 5-day period.

This experimental approach allowed us to calculate and remove the fecal and urinary output and methane loss resulting from the basal ration and isolate the digestibility, nitrogen retention, and metabolizable energy of juniper. This method resulted in a calculation of the net effect of juniper when added to the basal ration not necessarily the digestibility and nitrogen/energy balance of juniper alone (Maynard et al. 1979). We cannot assume that the digestion parameters calculated represent the actual digestion of juniper alone because the addition of juniper to the diet may have altered the digestibility of the basal ration (i.e., associative effect, Van Soest 1982). However, this method allowed us to compare breeds and treatments simply by assuming that possible associative effects between juniper and the basal ration were the same for all animals. Furthermore, this method allowed us to remove individual animal or breed variation related to digestion of the basal ration.

\section{Juniper with Basal Ration Digestion Trial}

During the adjustment period, juniper branches were offered ad libitum from 1500 to 1900 hours in the manner described for acceptance testing (Experiment 1). At 0800 hours, goats were offered an amount of a pelleted ration to meet maintenance protein and energy requirements (NRC 1985). The pelleted ration averaged $19 \%$ crude protein and was composed of ground alfalfa, cottonseed hulls, sorgham grain, corn, soybean meal, and molasses with a salt and trace mineral mix. Following the adjustment period, goats were placed in metabolism stalls located in an open-air building. Each stall measured $2.4 \times 1.1 \times 1.7 \mathrm{~m}$ with an expanded steel floor to allow feces to drop through to collection pans which were covered with $3 \mathrm{~mm}$-mesh wire screen. Urine ran through wire screens and was collected in plastic containers.

During the juniper with basal ration digestion trial, goats were offered the maintenance-level basal ration at 0800 hours and hand stripped juniper leaves from 1500 to 1900 hours. The leaves were stripped before initiation of digestion trials and stored in a freezer to insure a uniform quality of juniper throughout the trials. Leaves were thawed at room temperature daily, weighed and consumption was measured as the difference between juniper offered and refused. Moisture loss during each test was monitored in 3 boxes of stripped leaves and adjustments for moisture loss were made as described for acceptance testing.

Feces and urine were collected daily, measured, subsampled, and composited by animal over each 5-day collection period. Urine was sampled by volume. Volatilization of ammonia from urine was prevented by adding $10 \mathrm{ml}$ of $25 \% \mathrm{H}_{2} \mathrm{SO}_{4}$ to 4-liter (1gallon) plastic collection containers. Feces and urine samples were frozen until analyzed. Nitrogen and energy content of both urine and feces were determined with standard micro-Kjeldahl (AOAC 1984) and bomb calorimetry (Parr 1969, Maynard et al. 1979). Feces were oven dried at $50^{\circ} \mathrm{C}$ and ground to pass through $1 \mathrm{~mm}$ Wylie mill screen. Urine samples $(\sim 100 \mathrm{ml})$ for bomb calorimetry were freeze dried and percentage dry matter (DM) was calculated. Methane loss for each animal was estimated according to Blaxter and Clapperton (1965). Methane loss per $\mathrm{kcal}$ of fecd consumed, was calculated as $3.67+0.062 \mathrm{D}$; where $D$ was the apparent digestibility of dietary energy. We calculated apparent energy digestibility (\%) as [(GE of feed consumed Fecal GE - Urine GE)/ GE of feed consumed] * 100; where GE = gross energy expressed in kcals.

\section{Basal Ration Digestion Trial}

Basal ration conditioning and the basal ration digestion trial immediately followed the juniper digestion trial. During the conditioning and digestion trial, goats were given the pelleted ration at 0800 hours. Collection and analysis of feces and urine and calculations for methane loss were the same as in the juniper digestion trial.

\section{Digestion and Metabolism Calculations: \\ Juniper Dry Matter (DM) Digestibility (\%) = Juniper DM fed ${ }_{\mathrm{J}}+\mathrm{BR}-\left(\mathrm{FO}_{\mathrm{J}+\mathrm{BR}}-\mathrm{FO}_{\mathrm{BR}}\right) * 100$ Juniper DM fed J+BR}


Where: FO = Fecal Output on a dry matter basis;

${ }_{\mathrm{J}+\mathrm{BR}}=$ Quantity measured in digestion trial with juniper and basal ration; and

- BR = Quantity measured in digestion trial when animals were offered the basal ration only.

Juniper Nitrogen $(\mathrm{N})$ Retention $(\mathrm{mg})=$ Juniper $\mathbf{N}$ fed $\mathbf{J}+\mathrm{BR}$ $\left[\left(\mathrm{UN}_{\mathrm{J}}+\mathrm{BR}-\mathrm{UNBR}\right)+\left(\mathrm{FN}_{\mathrm{J}}+\mathrm{BR}^{-\mathrm{FN}_{\mathrm{BR}}}\right)\right]$

Where: UN = Urinary Nitrogen; and FN = Fecal $N$.

Juniper Potentially Available Metabolizable Energy (PAME) $=\mathrm{PAME}_{\mathrm{J}+\mathrm{BR}}-\mathrm{PAME}_{\mathrm{BR}}$

Where: PAME $_{\mathrm{J}+\mathrm{BR}}=$ Juniper GE fed $\mathrm{J}_{\mathrm{J}+\mathrm{BR}}-\mathrm{FGE}_{\mathrm{J}+\mathrm{BR}}-\mathrm{UGE}_{\mathrm{J}+\mathrm{BR}}$ - $\mathrm{ML}_{\mathrm{J}+\mathrm{BR}} ; \mathrm{PAME}_{\mathrm{BR}}=$ Basal ration $\mathrm{GE}$ fed $_{\mathrm{BR}}-\mathrm{FGE}_{\mathrm{BR}}-\mathrm{UGE}_{\mathrm{BR}}$ - $\mathrm{ML}_{\mathrm{BR}} ; \mathrm{GE}=$ Gross Energy; UGE = Urinary GE; FGE = Fecal $\mathrm{GE} ;$ and $\mathrm{ML}=$ Methane Loss

\section{Statistical Design}

The statistical design for the analysis of the digestion experiment was a $2 \times 2 \times 2$ factorial analysis of covariance (ANCOVA) with factors consisting of breed (Spanish or Angora), exposure (treated or controls), and previous acceptance (high or low; Hicks 1982). Juniper consumption was used as a covariate.

\section{Results and Discussion}

\section{Experiment 1: Juniper Acceptance}

Both breeds ingested a similar amount of juniper on day 1 of the trial (Fig. 1a). Spanish goats maintained greater consumption than Angora goats throughout the trial resulting in Spanish goats ingesting more $(p<0.01)$ total juniper than Angora goats. There was a breed by day interaction $(\mathrm{p}<0.01)$. Both breeds initially consumed high amounts of juniper suggesting that the flavor of juniper was not inherently offensive to either breed. However, consumption of juniper by Angora goats declined more sharply than for Spanish goats, suggesting that Angora goats experienced more postingestive distress (i.e., negative feedback) than Spanish goats. Contemporary diet selection theory suggests that the consumption of a food declines over time if negative postingestive consequences are experienced after consumption (Provenza 1996). Furthermore, the stronger the negative digestive feedback, the lower the future consumption of foods (duToit et al. 1991, Launchbaugh and Provenza 1994).

Goats that received essential oils early in life tended to ingest less $(p<0.086)$ juniper than control goats during the 5-day trial (Fig. 1b). Thus, early exposure to essential oils did not increase the goats abilities to ingest juniper later in life as had been anticipated. Essential oils may have caused damage to detoxification organs (e.g., liver or kidneys) or changes in rumen microbial populations making the group with prior exposure to essential oils less able to detoxify juniper ingested during the acceptance test.

\section{Blood Enzyme Analysis}

There was no difference in serum enzyme concentration due to exposure to essential oils during conditioning. Thus, values presented are averaged over previous exposure treatments. Lack of treatment differences in AST and GGT levels does not indicate that treatments had no detrimental effects on goats (as suggested above). It however confirms that exposure to essential oils did not affect specific metabolic activities involving AST and GGT
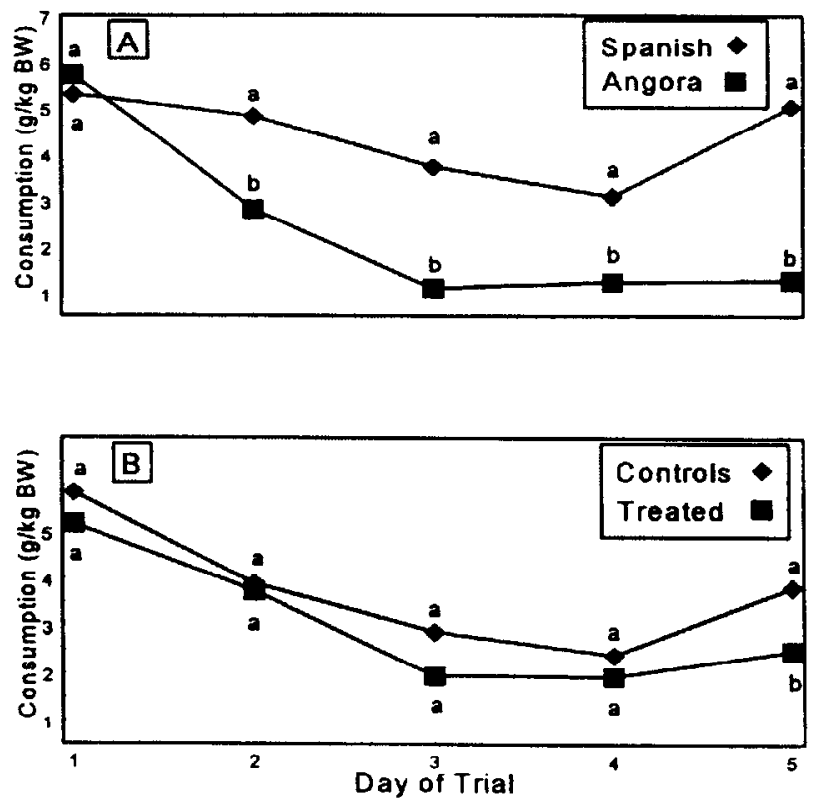

Fig. 1. A) Intake of redberry juniper (fresh weight) by Spanish (n $=24)$ and Angora $(n=24)$ goats. The overall difference between breeds was significant $(p<0.01)$. B) Redberry juniper intake (fresh weight) by goats exposed to essential oils (treated, $n=24$ ) or not exposed to essential oils (control, $n=24$ ) for 1 month. The overall difference between treatment groups was marginally significant $(p<0.086)$. Breed means and treatment means, on any day, followed by the same letter were not significantly different $(p>0.05)$.

\section{(Duncan and Prasse 1986).}

Serum AST concentrations did not differ $(p>0.05)$ between breeds (Fig. 2a) following conditioning. By the end of the 5-day acceptance test, AST serum concentrations had increased for both breeds. However, AST concentrations for Angora goats were more elevated than for Spanish goats, resulting in a breed by collection period interaction $(p<0.065)$. This increase in enzyme concentration suggests that both breeds incurred damage to liver or other tissue during the acceptance test when they were given diets of juniper. The interaction supports the hypothesis that Angora goats were more negatively affected than Spanish goats.

Serum AST concentrations were not affected by exposure to essential oils during the conditioning period and yet AST concentrations increased when animals ate fresh juniper. This apparent contradiction, may result from differences in the terpene composition or amount of essential oils used in conditioning and the composition or amount of essential oils in the fresh juniper offered in acceptance tests. It is likely that the most volatile terpenes were partially lost in the distillation process to prepare essential oils for conditioning. It is also possible that the junipers distilled for the conditioning procedure contained less essential oils or oils of different terpene composition than the junipers that were used in the acceptance tests, collected nearly 2 months later.

Serum GGT concentrations were not different between breeds before the acceptance test (Fig. 2b). The GGT concentration for Angora goats decreased and were lower than serum concentration for Spanish goats by the end of the trial whereas Spanish goats maintained similar GGT concentration throughout the trial. An 

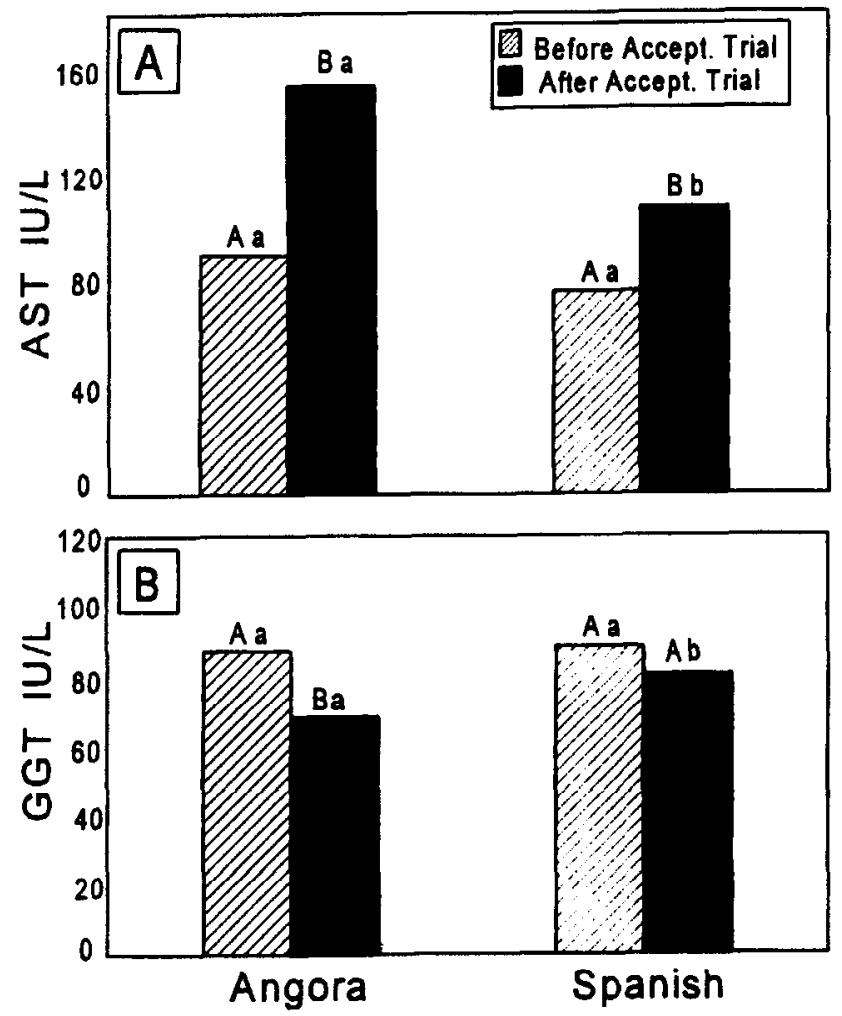

Fig. 2. Average (A) aspartate aminotransferase (AST) and (B) gamma glutamyltransferase (GGT) concentrations in serum of Angora and Spanish goats before and after a 5-day acceptance test with redberry juniper. Differences between a collection period within a breed followed by the same upper case letter were not different $(p>0.05)$. Breed means within a collection period with the same lower case letter were not different $(p>0.05)$.

increase in serum GGT would be a good indicator of liver damage (cholestasis) in ruminants. However, a decrease in GGT of this small magnitude has little diagnostic value (Ducan and Prasse 1986).

\section{Experiment 2: Juniper Digestibility and Metabolism}

All goats consistently ate all of the maintenance-level basal ration they were offered. Spanish goats consumed more $(p<0.01)$ juniper than Angora goats during the juniper digestion trial (Fig. 3 ). The higher juniper intake again indicates that Spanish goats have a greater ability to tolerate or avoid (through detoxification) the negative consequences of juniper consumption. There was no difference ( $p>0.05$ ) in juniper intake between goats that received doses of essential oils early in life and those that did not.

Goats with low juniper consumption in the acceptance test ate more $(p<0.01)$ juniper than those with high juniper consumption during the acceptance test. Apparently, high juniper consumption during the acceptance experiment limited the ability of goats to cope with essential oils during the digestion experiment.

\section{Apparent Digestibility}

Level of juniper consumption during the acceptance trial (high vs low) did not significantly affect digestibility, nitrogen retention, or potentially available metabolizable energy, therefore it was removed from the model and results for only breed and prior exposure will be discussed. Exposure to essential oils early in life had no effect on apparent digestibility $(p>0.05)$.

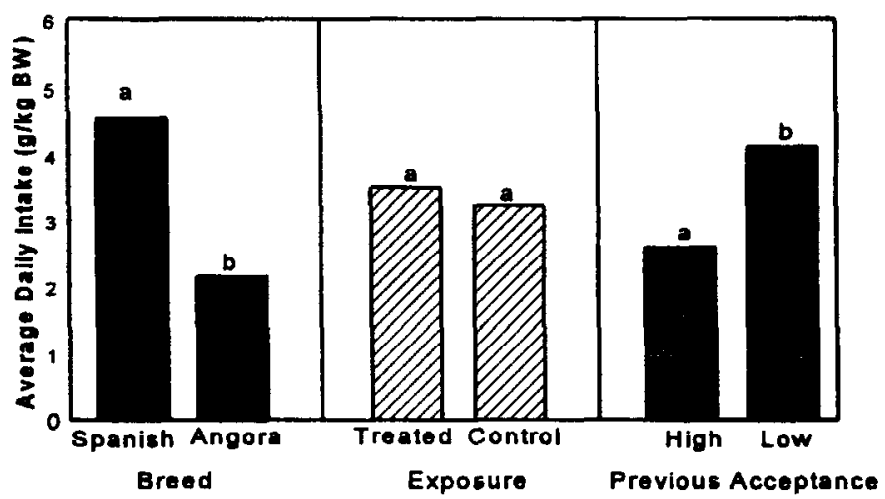

Fig. 3. Intake of redberry juniper (fresh weight) by goats during a 5day metabolism trial. Each value represents the mean of 16 goats. Intake is compared for goats of different breeds (Spanish vs Angora), exposure to essential oils early in life (Treated vs Control), and acceptance of juniper (High vs Low) in a previous juniper acceptance trial. Means within main effects with different lower case letters differ significantly $(p<0.05)$.

Angora goats digested juniper more completely than Spanish goats $(p<0.01)$ and there was a breed $X$ juniper consumption interaction ( $p=0.01$; Fig. 4$)$. The digestibility of juniper by Angora goats declined as consumption increased while juniper digestibility was unaffected by consumption level in Spanish goats. However, there was no difference $(p>0.05)$ between breeds when the analysis was restricted to a range of consumption within which both breeds were represented (Fig. 4). It appears that digestibility of juniper has a curvilinear response to increased consumption. At low consumption levels, juniper was highly digestible and as consumption increased digestibility deceased until it reached a fixed level. It is common for forages to be highly digestible at very low intake levels and become less digestible as voluntary intake increases (Van Soest 1982). Essential oils may have more severely limited juniper consumption by Angora goats than Spanish goats and lower consumption resulted in higher digestibility for Angora goats.

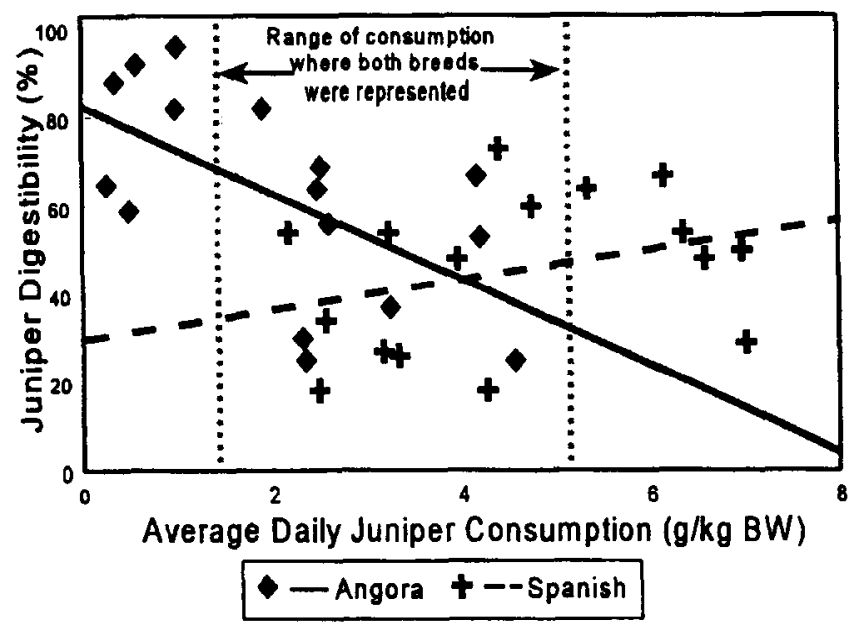

Fig. 4. Apparent digestibility of fresh redberry juniper by Spanish and Angora goats in a 5-day metabolism trial. 


\section{Nitrogen Retention}

There was no effect of prior exposure to essential oils on nitrogen retention. Spanish and Angora goats had similar nitrogen retention and both breeds averaged a negative nitrogen balance (Fig. 5a). This indicates that the metabolism of juniper required more nitrogen than goats were provided by the juniper. There were no differences between breeds in the amount of nitrogen in the feces or urine (Fig. $5 \mathrm{~b}, \mathrm{c})$. Nitrogen in the feces increased as juniper consumption increased for both breeds. The amount of nitrogen in the urine of
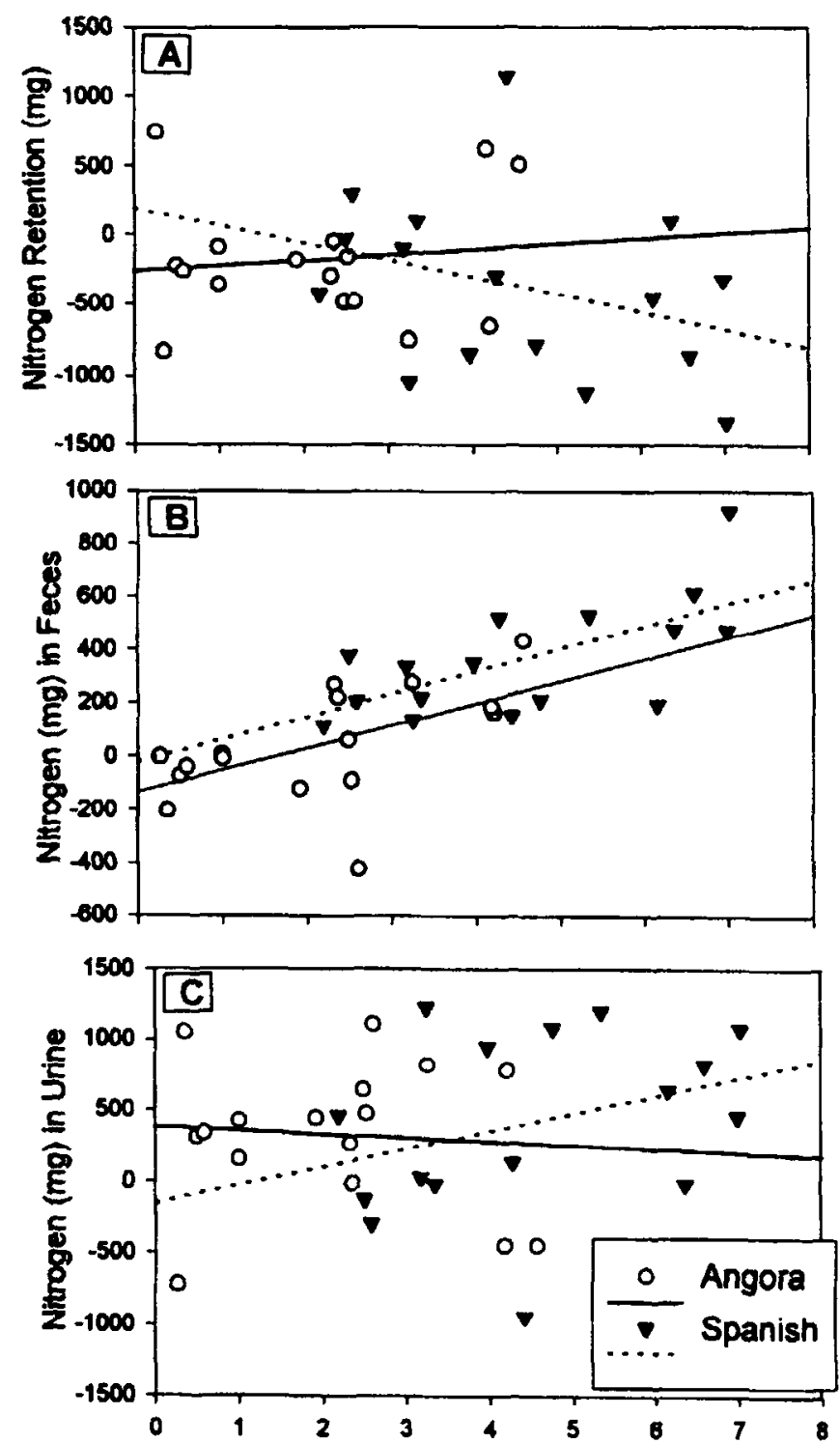

Average Daily Juniper Consumption ( $g / \mathrm{kg}$ BW)

Fig. 5. Nitrogen retention and nitrogen excreted in feces and urine by Spanish and Angora goats during the 5-day redberry juniper metabolism trial. Regression equations were as follows: Nitrogen retention for Spanish goats equaled $190.4-122.7 \times\left(r^{2}=.11\right)$, and for Angora goats equaled - $264.7+39.8 \times\left(r^{2}=.02\right)$. Nitrogen in feces for Spanish goats equaled $-21.4+85.6 \times\left(r^{2}=.43\right)$, and for Angora goats equaled $-134.1+83.2 \times\left(r^{2}=.32\right)$. Nitrogen in urine for Spanish goats equaled $-152.8+127.0 \times\left(r^{2}=.11\right)$, and for Angora goats equaled 381.9-24.7 $\times\left(r^{2}=.01\right)$.
Angora goats was the same as Spanish goats which had higher intake. This can be explained by the differences in juniper digestibility; Angora goats ate less juniper but digested it more fully, resulting in no difference in nitrogen retention.

\section{Metabolizable Energy}

There was no effect of prior exposure or goat breed on the potentially available metabolizable energy of juniper (Fig. 6a). Both breeds were in a positive energy balance thus, the goats
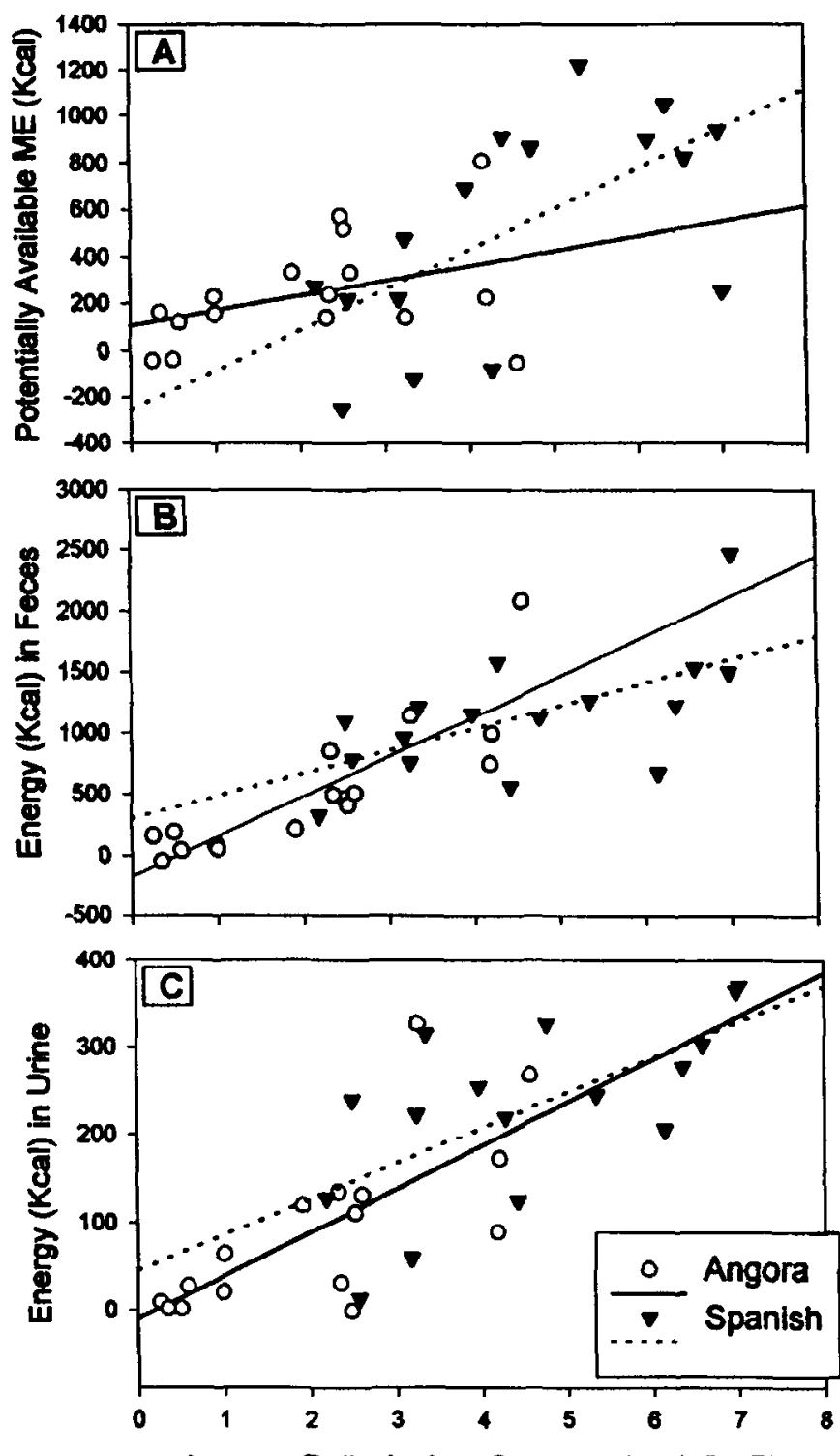

Average Daily Juniper Consumption ( $(\mathrm{kgg}$ BW)

Fig. 6. Potentially available metabolizable energy and gross energy excreted in feces and urine by Spanish and Angora goats during the 5-day redberry juniper metabolism trial. Regression equations were as follows: Metabolizable energy for Spanish goats equaled $245.4+171.4 \times\left(r^{2}=39\right)$, and for Angora goats equaled 107.3 + 63.7 y $\left(r^{2}=.15\right)$. Energy in feces for Spanish goats equaled $298.9+$ $185.9 \times\left(r^{2}=.38\right)$, and for Angora goats equaled - 169.5 + 326.3 x $\left(r^{2}=.72\right)$. Energy in urine for Spanish goats equaled $46.0+40.5 x$ $\left(r^{2}=.43\right)$, and for Angora goats equaled $-9.9+49.3 \times\left(r^{2}=.52\right)$. 
obtained some energy from the digestion of juniper. Gross energy in the feces was positively related to juniper consumption and did not differ by breed (Fig. 6b). Urinary energy was also similar between breeds and as juniper consumption increased, urinary gross energy increased (Fig. 6c).

\section{Summary and Management Implications}

Spanish goats are clearly more willing to eat juniper than Angora goats and are, therefore, better adapted for use in juniper biological control programs. However, the physiological mechanisms responsible for this breed difference are not fully understood. Our research suggests that one facet of study deserving more attention is detoxification or tolerance of essential oils by goats. Understanding what makes these 2 breeds different relative to juniper consumption may lead to management practices that increase the consumption of juniper on rangelands.

Even though Spanish goats consumed more juniper, there was substantial overlap in levels of juniper consumption between Spanish and Angora goats. About 25\% of the Angora goats consumed more juniper than the average Spanish goat. Therefore, if the production of Spanish goats is not a practical or desirable management alternative, selection within an Angora goat population could be a useful tool to increase juniper consumption.

Our research also suggests that use of goats in juniper control programs, where substantial juniper consumption is required, may negatively affect the nitrogen balance of animals. Supplementation of protein may be more important than energy supplementation and could increase juniper use while maintaining goats in a positive nutritional balance.

\section{Literature Cited}

AOAC. 1984. Official methods of analysis. (14th Ed). Assoc. of Official Analytical Chem., Washington, D.C.

Bratmann, R.M. and L.H. Carpenter. 1982. Effects of foraging experience on food selectivity of tame mule deer. J. Wildl. Manage. 46:813-818.

Blaxter, K.L. and J.L. Clapperton. 1965. Prediction of the amount of methane produced by ruminants. Br. J. Nutr. 19:511-522.

Clevenger, J.F. 1928. Apparatus for the determination of volatile oil. J. Amer. Pharm. Assoc. 17:345-349.

Cornelius, C.E. 1980. Liver function. p. 201-257. In: J.J. Kaneko (ed.), Clinical biochemistry of domestic animals. Academic Press, New York, N.Y.

Distel, R.A. and F.D. Provenza. 1991. Experience early in life affects voluntary intake of blackbrush by goats. J. Chem. Ecol. 17:431-450.

Dye II, K.L., D.N. Ueckert, and S.G Whisenant. 1995. Redberry juniper-herbaceous understory interactions. J. Range Manage. 48:100-107.

Duncan, J.R. and K.W. Prasse. 1986. Veterinary laboratory medicine: clinical pathology. Iowa State Univ. Press, Ames, Iowa.

duToit, J.T., F.D. Provenza, and A. Nastis. 1991. Conditioned taste aversions: How sick must a ruminant get before it learns about toxicity in foods? Appl. Anim. Behav. Sci. 30:35-46.

Gershenzon, J. and R. Croteau. 1991. Terpenoids. p. 165-219. In: G.A Rosenthal and M.R. Berenbaum (eds.), Herbivores: their interactions with secondary plant metabolites. Academic Press, San Diego, Calif.

Hicks, C.R. 1982. Fundamental concepts in the design of experiments. Saunders College Pub., Fort Worth, Tex.

Higgins, D., K. Launchbaugh, E. Straka, and C. Taylor. 1996. Reasons for differential palatability of ashe and redberry juniper to goats. p. 89. In: Abstracts of 49th Ann. Meeting, Soc. for Range Manage., Vol. 49.
Huston, E., C.A. Taylor, and E.J. Straka. 1994. Effects of juniper on livestock production, p. 45-51. In: Proc. 1994 juniper symposium. Texas Agr. Res. Sta. Tech. Rep. 94-2. Sonora, Tex.

Launchbaugh, K.L. 1996. Biochemical aspects of grazing behavior. p. 159-184. In: J. Hodgeson and A.W. Illius (eds.), The Ecology and management of grazing systems. CAB International, Wallingford, U.K.

Launchbaugh, K.L. and F.D Provenza. 1994. The effects of flavor concentration and toxin dose on the formation and generalization of flavor aversions in lambs. J. Anim. Sci. 72:10-13.

Lindroth, R.L. 1988. Adaptations of mammalian herbivores to plant chemical defenses. p. 415-445. In: K.C. Spencer (ed.), Chemical mediation of coevolution. Academic Press, San Diego, Calif.

Maynard, L.A., J.K. Loosli, H.F. Hintz, and R.G. Warner. 1979. Animal nutrition (7th ed.). McGraw-Hill Book Co., New York, N.Y.

McCurnin, D.M. 1990. Clinical textbook for veterinary technicians. W.B. Saunders Co. Harcourt Brace Jovanovich Inc., Philadelphia, Penn.

Nagy, J.G. and R.P. Tengerdy. 1968. Antibacterial action of Artemisia as an ecological factor. II. Antibacterial action of volatile oils of Artemisia tridentata (big sagebrush) on bacteria from rumen of mule deer. Appl. Microbiol. 16:441-444.

NRC (National Research Council). 1985. Nutrient requirements of sheep (6th ed.). National Academy Press, Washington, D.C.

Oh, H.K., T. Sakai, M.B. Jones, and W.M. Longhurst. 1967. Effect of various essential oils isolated from douglas fir needles upon sheep and deer rumen microbial activity. Appl. Microbiol. 15:777-784.

Parr. 1969. Instruction for 1241 and 1242 calorimeters. Manual no. 142. Parr Instrument Co. Moline, Ill.

Provenza, F.D. 1996. Acquired aversions as the basis for the varied diets of ruminants foraging on rangelands. J. Anim. Sci., 74:2010-2020.

Provenza, F.D. and D.F. Balph. 1988. The development of dietary choice in livestock on rangelands and its implications for management. J. Anim. Sci. 66:2356-2368.

Provenza, F.D., J.A. Pfister, and C.D. Cheney. 1992. Mechanisms of learning in diet selection with reference to phytotoxicosis in herbivores. J. Range Manage. 45:36-45.

Radostits, O.M., D.C. Blood, and C.C. Gay. 1994. Veterinary medicine: a textbook of the diseases of cattle, sheep, pigs, goats, and horses. Bailliere Tindall, Philadelphia, Penn.

Riddle, R.R. 1993. Seasonal effects of volatile oils in Ashe and redberry juniper on preference and digestibility by goats. M.S. Thesis. Texas A\&M Univ., College Station, Tex.

Schoot, M.R. and R.D. Pieper. 1985. Influence of canopy characteristics of one-seed juniper on understory grasses. J. Range Manage. 38:328-331.

Schwartz, C.C., J.G. Nagy, and W.L. Regelin. 1980. Juniper oil yield, terpenoid concentration, and antimicrobial effects on deer. J. Wildl. Manage. 44:107-113.

Smith, A.D. and R.L. Hubbard. 1954. Preference ratings for winter deer forages from northern Utah ranges based on browsing time and forage consumed. J. Range Manage. 7:262-265.

Squibb, R.C., Provenza, F.D., and Balph, D.F. 1990. Effect of age of exposure on consumption of a shrub by sheep. J. Anim. Sci. 68:987-997.

Straka, E.J. 1993. Preferences for redberry and blueberry juniper exhibited by cattle, sheep, and goats. M.S. Thesis. Texas A\&M Univ., College Station, Tex.

Taylor, C.A. 1992. Brush management considerations with goats. p. 144-155. In: J.C. Paschel, and W. Hanselka (ed.), Proc. of the International conference on meat goat production. Tex. Agr. Ext. Serv., College Station, Tex.

Van Soest, P.J. 1982. Nutritional ecology of the ruminant. Cornell University Press, Ithaca, N.Y.

West, N.E. 1991. Junipers of the Western U.S.: Classification, distribution, ecology, and control, p. 325-333. In: L.F. James (ed.), Noxious range weeds. Westview Press, Boulder, Colo.

Winer, B.V. 1971. Statistical principles in experimental design. McGraw-Hill, New York, N.Y. 